\title{
Correspondence
}

We try to publish authors' responses in the same edition with readers' comments. Time constraints might prevent this in some cases. The problem is compounded in a bimonthly journal where continuity of comment and redress are difficult to achieve. When the redress appears 2 months after the comment, 4 months will have passed since the article was published. Therefore, we would suggest to our readers that their correspondence about published papers be submitted as soon as possible after the article appears.

\section{Haste in Starting Therapy for Depression}

To the Editor: The article titled "Depression Treatment in Primary Care" by Robinson et $\mathrm{al}^{1}$ is very well written and comprehensively scores the need to reassess the type of therapy offered. Having gone through the article, we are impelled to write a few of our observations, in the hope that we might contribute to the research on treatment of the geriatric population.

Is there a haste involved in starting the therapy for depression, especially in the geriatric population? There should be a need to reflect why less than $5 \%$ of the patients were grouped into the "watchful waiting" and "support group" categories. ${ }^{1}$ Moreover, for the geriatric age group, multifaceted interventions and principles of collaborative care result in best outcomes. ${ }^{1,2}$ Were the patients given a choice or was it that the interplay of the capacity to pay and the type of insurance held that had determined the modality of treatment. We propose introspection by the readers on the above issues, in the backdrop of a research finding expressing the preference of geriatric patients for psychological interventions. ${ }^{3}$

Akhilesh Kumar Singh, MBBS, MD

Institute of Human Behavior and Allied Sciences Delhi, India

Rajesh Chauhan, MBBS, DFM, FCGP, ADHA, FISCD

Consultant

Family Medicine and Communicable Diseases Parul Kushwah, MBBS, MISCD

Family Medicine Practitioner

\section{References}

1. Robinson WD, Geske JA, Prest LA, Barnacle R. Depression treatment in primary care. J Am Board Fam Pract 2005;18: $79-86$.

2. Chew-Graham C, Baldwin R, Burns A. Treating depression in later life. BMJ 2004;329:181-2.

3. Unützer J, Katon W, Callahan CM, et al. Collaborative care management of late life depression in the primary care setting. JAMA 2002;288:2836-45.

The above letter was referred to the authors of the article in question, who offer the following reply.
To the Editor: We appreciate the comments regarding our article, and agree with the authors of the letter that treatment of depression in the elderly is an important area that warrants further research. Our study did not specifically look at the treatment of depression in the elderly, and we do not have sufficient numbers in our data to address this topic specifically. We would encourage researchers to address this topic. The biological comorbidities, the psychological adjustments, the social stressors, and the existential search for meaning that occur through the aging process make depression more likely to occur and more complicated to treat.

$$
\begin{array}{r}
\text { W. David Robinson, PhD } \\
\text { Jenenne A. Geske, PhD } \\
\text { Layne A. Prest, PhD } \\
\text { Department of Family Medicine } \\
\text { University of Nebraska Medical Center } \\
\text { Omaha, Nebraska }
\end{array}
$$

\section{References}

1. Robinson WD, Geske JA, Prest LA, Barnacle R. Depression treatment in primary care. J Am Board Fam Pract 2005;18 $79-86$.

\section{Fish Oil versus Cod Liver Oil: Is Vitamin D a Reason to Go Back to the Future}

To the Editor: As Dr. $\mathrm{Oh}^{1}$ points out in his article, fish oil supplementation has gained popularity in recent years because of the many health benefits of omega-3 longchain polyunsaturated fatty acids (LCPUFAs). Dr. Oh's article provides a thorough review of the literature on this topic and recommendations for fish oil supplementation. However, although fish oil is an excellent source of omega-3 LCPUFAs, it doesn't provide the significant levels of vitamin D that cod liver oil does. ${ }^{2}$ Vitamin D is concentrated in the liver of the fish and thus plentiful in cod liver oil, a time-honored source of vitamin D. Fish oil is made from the whole body of the fish and has an insignificant amount of vitamin D.

Hypovitaminosis D is a significant public health concern. ${ }^{3-5}$ In a study of healthy adolescents, Gordon et $\mathrm{al}^{5}$ found that $24.1 \%$ were vitamin D deficient and $42.0 \%$ were vitamin $\mathrm{D}$ insufficient. LeBoff et $\mathrm{al}^{4}$ found an association between hip fractures in older women and lower levels of 25-hydroxyvitamin D. Vitamin D deficiency may contribute to metabolic syndrome. ${ }^{6,7}$ Vitamin $\mathrm{D}$ seems to play a protective role against breast, prostate, and colon cancer. ${ }^{8}$ Animal experiments link vitamin $\mathrm{D}$ deficiency to abnormal brain development. The broad spectrum of effects from suboptimal levels of vitamin D reflect its varied functions. Vitamin D plays important roles in bone health and mineral homeostasis, immune modulation, muscle function, nervous system function, control of the renin-angiotensin system, con- 
trol of insulin secretion, skin function, regulation of apoptosis, and regulation of cell growth.

Cod liver oil contains both vitamin D and omega-3 LCPUFAs. $^{2}$ Individuals at higher risk for vitamin D deficiency may wish to consider substituting cod liver oil for fish oil supplementation.

Celia M. Ross, MS Wilmington, DE

\section{References}

1. Oh R. Practical applications of fish oil (omega-3 fatty acids) in primary care. J Am Board Fam Pract 2005;18:28-36.

2. Linday LA, Dolitsky JN, Shindledecker RD. Nutritional supplements as adjunctive therapy for children with chronic/recurrent sinusitis: pilot research. Int J Pediatr Otorhinolaryngol 2004;68:785-93.

3. Thomas MK, Demay MB. Vitamin D deficiency and disorders of vitamin D metabolism. Endocrinol Metab Clin North Am 2000;29:611-27, viii.

4. LeBoff MS, Kohlmeier L, Hurwitz S, et al. Occult vitamin $\mathrm{D}$ deficiency in postmenopausal US women with acute hip fracture. JAMA 1999;281:1505-11.

5. Gordon CM, DePeter KC, Feldman HA, et al. Prevalence of vitamin $\mathrm{D}$ deficiency among healthy adolescents. Arch Pediatr Adolesc Med 2004;158:531-7.

6. Ford ES, Ajani UA, McGuire LC, Liu S. Concentrations of serum vitamin $\mathrm{D}$ and the metabolic syndrome among U.S. adults. Diabetes Care 2005;28:1228-30.

7. Boucher BJ. Inadequate vitamin D status: does it contribute to the disorders comprising syndrome ' $\mathrm{X}$ '? Br J Nutr 1998; $79: 315-27$

8. Dusso AS, Brown AJ, Slatopolsky E. Vitamin D. Am J Physiol Renal Physiol 2005;289:F8-F28.

The above letter was referred to the authors of the article in question, who offer the following reply.

To the Editor: I thank Ms. Ross for the comments on my article. I too feel strongly that physicians under-appreciate and under-recognize mild vitamin $\mathrm{D}$ deficiency. ${ }^{1} \mathrm{Al}-$ though cod liver oil is rich in vitamin $\mathrm{D}$, most formulations do not have enough omega-3 fatty acids (FA) for it to be practical in clinical use. In an informal survey I performed, I found that typical preparations contain approximately 50 to $90 \mathrm{mg}$ of omega-3 FA (compared with $300 \mathrm{mg}$ in fish oil). ${ }^{2}$ To reach 1 to $4 \mathrm{~g}$ of omega-3 FA (doses needed for secondary prevention of cardiovascular disease, rheumatoid arthritis, and hypertriglyceridemia) ${ }^{2}$ one would have to ingest 10 to 40 capsules of cod liver oil daily.

In addition, cod liver oil contains approximately 135 IU of vitamin D and 2500 IU of vitamin A in each capsule. Toxic doses of vitamin A can occur if cod liver oil is given in doses typical for treatment of hypertriglyceridemia and rheumatoid arthritis ( 2 to $4 \mathrm{~g}$ ). Studies have also linked chronic daily vitamin A intake to increased fracture risk and teratogenicity. ${ }^{3-5}$ Cod liver oil may potentially be used for conditions requiring supplementation of vitamin A and D but should generally be avoided for conditions requiring high levels of omega-3 FA. Other formulations may contain higher levels of omega-3 FA, but consumers and physicians must be especially cognizant of the amount of vitamin D and vitamin $\mathrm{A}$ that are contained in the preparation to avoid toxicity.

Even typical fish oil supplements may be difficult to provide 2 to $3 \mathrm{~g}$ of omega- $3 \mathrm{FA}$, and physicians should consider prescribing highly concentrated formulations. Recently, the Food and Drug Administration has approved a prescription form of omega-3 FA containing approximately $900 \mathrm{mg}$ of omega-3 FA in each capsule. ${ }^{6}$ Although only approved for the treatment of hypertriglyceridemia, physicians can also consider this formulation in off-label uses for secondary prevention of cardiovascular disease and rheumatoid arthritis to minimize the number of capsules that patients have to take.

Robert C. Oh, MD

Department of Family Medicine Tripler Army Medical Center Honolulu, HI

\section{References}

1. Oh R. Vitamin D insufficiency as a cause of hyperparathyroidism. Am Fam Physician 2005;71:46,49.

2. Oh R. Practical applications of fish oil (omega-3 fatty acids) in primary care. J Am Board Fam Pract 2005;18:28-36.

3. Feskanich D, Singh V, Willett WC, Colditz GA. Vitamin A intake and hip fractures among postmenopausal women. JAMA 2002;287:47-54.

4. Michaelsson K, Lithell H, Vessby B, Melhus H. Serum retinol levels and the risk of fracture. N Engl J Med 2003; 348:287-94.

5. Rothman KJ, Moore LL, Singer MR, et al. Teratogenicity of high vitamin A intake. N Engl J Med 1995;333:1369-73.

6. Omacor. Consumer drug information sheet. U.S. Food and Drug Administration. Accessed on July 4, 2005 at: http:// www.fda.gov/cder/consumerinfo/druginfo/omacor.htm 